\title{
DOUBLE TAXATION CONVENTIONS, STRUCTURE AND EVOLUTION OF THE AMERICAN TAX SYSTEM
}

\author{
Florin Dumiter $\mathbf{P h D}^{1,2}$ \\ 1"Vasile Goldis" Western University of Arad \\ ${ }^{2}$ West University of Timisoara, Faculty of Law, PhD Candidate \\ E-mail: fdumiter@yahoo.com \\ Daniel Berlingher PhD \\ "Vasile Goldis" Western University of Arad \\ E-mail: berlingherdaniel@yahoo.com \\ Anca Opret PhD Candidate \\ Bucharest Academy of Economic Studies \\ E-mail: ancaopret@yahoo.com \\ Silvia Todor PhD Candidate \\ Bucharest Academy of Economic Studies \\ E-mail: silvia_paula27@yahoo.com
}

(Received December 2015; Accepted February 2016)

\begin{abstract}
This article is intended as a retrospective survey of the comprehensiveness of the tax system, in the broad sense, and the US tax system, in a stricter sense, in terms of structuring model and application of tax levies, as well as the taxation applied to each public financial income category. The topic chosen is based on the idea that the US tax system is different from the European system, while also considering that the USA is the world leader in business, trade and investment, and seen as a true "streamliner" of the world. The US economy is strongly influenced by sectors that prevail at the federal level: industry, education, trade, telecommunications, and transportation. The research methodology used in this article consists of a comprehensive analysis of key concepts regarding tax levying activities, providing an explanation of the tax policy, a critical analysis of the US system in terms of tax legislation, and a history of international double taxation conventions concluded by the US with other countries, given that the USA may be an archetype (best practice) in terms of the double taxation agreements network, regarding both the number of countries with which they have been concluded, and the types of agreements on income and capital. In our opinion, the results of this study indicate the optimal technical framework used by the American system to identify and implement the most sustainable methods, techniques and procedures in order to reduce the scope of international double taxation on income and capital worldwide.
\end{abstract}

Key words: tax policy, double taxation conventions, US tax system, tax conformity, tax treatment. 
Dumiter F., Berlingher D., Opret A., Todor S. (2016)

Double taxation conventions, structure and evolution of the american tax system

\section{Introduction}

The USA is a federal republic with autonomous states and local governments, so that taxes are levied in each of these. These include taxes on income, property, sales, import, payroll and also various fees.

Taxes on the net income of individuals and corporations are levied by the federal government, most states and by some local governments. Residents are taxed on total taxable income.

Taxable income is determined by the legislation, without considering tax principles, and includes almost all types of income, irrespective of background. Most business expenditure reduces taxable income, but there are some limitations for certain categories of expenditure. Individuals are allowed to reduce taxable income by personal allowances and certain expenses not related to business expenditure, including mortgage interest, state and local taxes, charitable and medical contributions. Most often, state taxation principles differ from federal regulations. Federal tax rates range from $15 \%$ to $35 \%$ of taxable income, while state and local ones vary by jurisdiction, being most often progressive. In general, state taxes are treated as a deductible expense from the calculation of federal tax.

Whether this is considered feasible or not, currently, government interventionism in the economy is considerable, much more so than a century ago. Indeed, government interventionism is even higher than suggested by some statistics (e.g., amount of proceeds from federal taxes is about $20 \%$ of GDP), since it intervenes in the economy through taxes and the many tax and financial regulations that affect every aspect of economic life. Thus, federal expenditure accounts for two-thirds of total spending on taxes.

One of every three dollars of total revenue of the US economy goes to the government. Unsurprisingly, there is great concern about how the government increases its revenues. Nobody loves taxes, but they are necessary given that the government provides necessary public goods and services and redistributes income to ensure a certain degree of fairness in society. Sometimes it seems that everybody wants more public services, but wants to pay as little for them as possible.

This can be achieved if the government increases its efficiency. However, over time, there have been significant increases in this area. In 2000, for example, the number of federal employees was smaller than it had been 30 years before, even though the number of people serviced and the scope of government programs have soared (in contrast, state and local governments have increased the number of civil servants by $85 \%$ in 30 years). Obviously, there are limits to these improvements in efficiency, at least in the short term, and reducing taxes leads to either higher deficits or reduced government programs; as such, this is not a good area to experiment. Voters chose repeatedly against politicians who had promised tax cuts, especially because they believe that the benefits they receive from key government programs are worth the costs incurred. 
In the past 30 years, the tax system in the US has experienced six major reforms: 1981, 1986, 1993, 1997, 2001 and 2005. In recent years, more and more voices have been calling for a new reform, and rightly so since the US tax system has problems in the context of the current global crisis. The reasoning for all reforms was to make the system as efficient, accurate and easy to administer as possible. But each of the reforms was faced with certain compromises; they were stronger than others, and each tried to make up for what was widely viewed as an excess of the previous reform. Meanwhile, a concern for maintaining government spending limits their expansion, so it is very difficult for various social goals to be achieved through existing programs. Therefore, tax expenditures and the continuation of certain targets in the legislative reforms of 1993, 1997 and 2001 led to a virtually inevitable "complication" of the tax system.

The average taxation rate determines the proportion of taxation for taxable income. While there may be spikes in marginal taxation rate, the average rate of taxation experiences a small growth over time. Income tax is only one of several taxes on revenue that US citizens pay. Payroll tax (and social welfare) is another form of tax whose level increases with income, up to a certain level. Crediting of tax on income from active work is intended to supplement income for families of lowincome workers, so as a person's income increases above a certain level, the revenue that they receive as a result of this program decreases.

To assess the overall efficiency of the tax system in the US, we must take into account not only federal taxes, but all taxes, including corporate income tax and local taxes. Many state and local taxes are regressive. This is because people with low and middle income use a greater share of their income on items that are subject to state taxation on sales compared to the rich. Overall, the current US tax system combining some of the progressive federal tax system with some of the state and local regressive tax system - is believed by many economists to only be partially progressive.

\section{Specific features of the US tax system}

Criteria for assessing a tax system show that the US government collects tax revenues from a variety of sources. There are taxes on the incomes of each person or some corporations, known as total income taxes (for individuals) and corporate taxes. Real property - land and buildings - is subject to taxation in most states, such taxes being known as property (millage) taxes. Inheritances and donations are also taxed. There are special provisions related to capital gains taxes (increase in the value of an asset between the time of purchase and the time it is sold). Moreover, wage income is subject not only to income tax, but also to payroll tax (tax levied on a company's payroll and which is deducted from employees' checks). Revenues from payroll taxes also fund social welfare (pension revenue) and healthcare programs - Medicare (health insurance for the elderly). 
Dumiter F., Berlingher D., Opret A., Todor S. (2016)

Double taxation conventions, structure and evolution of the american tax system

There are also taxes set on certain goods and services, known as excise duties. The most burdensome excise duties are set on alcoholic drinks and tobacco, also known as sin taxes. Excise duties set on air travel and fuels are sometimes called benefit taxes, because they are used to improve airports or roads which taxpayers will benefit from. Excise duties on perfumes, high cylinder capacity vehicles, yachts and furs, and generally goods that are sought more by the rich, are known as luxury taxes. Such excise duties, such as those for telephone services, have no other purpose than to increase revenue.

Most states levy a general tax on the purchase of goods and provision of services, known as sales taxes, although a variety of items (such as food) are exempt.

As regards the existence of an ideal tax system, as globally this goal is impossible, the US tax system cannot be excluded from this equation. However, we should consider some of the elements of an efficient tax system as applied to the US tax system, namely:

- Efficiency - the US tax system cannot be considered as an efficient one, given the successive changes of recent years and the need to change and improve some elements. The inefficiency of this system is caused by the progressivity of the tax system and the extent to which different forms of revenue and expenditure are treated differently. Successive changes in tax legislation did not provide the desired results, but have created even more serious distortions.

- Administrative simplicity - the entire US tax system is a complex system involving rules applicable at federal level, then at state level. The high taxation level for certain categories of persons acting individually and within various businesses requires the identification and application of different ways to hide the value or quantity of goods produced, precisely in order to escape the actual payment of tax incumbent on the result of activities undertaken. The complexity of this system is derived from trying to have a progressive income tax and to tax capital income.

- Flexibility - the US tax system can be severely criticized as far as flexibility is concerned, as numerous discussions on changes needed in taxation are stagnating or are addressing the issue from different angles - which social categories will be favored or disfavored by some changes? It is clear that things are stagnating and will probably stagnate in the near future in order to not provide favorable treatment for a certain category of persons; thus, the whole system has proved difficult and cumbersome in proposing a set of amendments to tax laws.

- Transparency - another problem is the lack of transparency of the tax system. Deliberately, the government considers that taxpayers do not need to know the actual amount of taxes they pay. Governments fear that if taxpayers know these values, they will be shocked and will tend to increase opposition / resistance to paying taxes. 
Dumiter F., Berlingher D., Opret A., Todor S. (2016)

Double taxation conventions, structure and evolution of the american tax system

\section{Personal income taxes}

The US tax system sets a mandatory tax on the income of individuals, corporations, households, and trusts. This is calculated from taxable income, as defined, multiplied by a specified tax rate. This tax may be reduced by tax credits, some of which may be reimbursed if they exceed the calculated tax (IRS.gov Publication 542, 2006).

Taxable income may differ from income used for other purposes (such as for financial reporting). The definition of federal taxable income is used most often, but not in all states. Thus, income and deductions are recognized in accordance with tax regulations, and there are variations between states.

According to the US tax system, individuals, corporations, households, and trusts are subject to income tax. Partnerships are not taxed, but rather their partners are subject to income tax (i.e. shares, income and deductions). However, some types of business entities can choose to be treated as corporations or as partnerships.

Taxpayers must file their tax returns and self-assess their tax. The tax may be deducted from income among taxpayers (e.g. deducting taxes from wages). To avoid situations where the tax is not covered by deductions, taxpayers must make estimated tax payments, generally on a quarterly basis. Tax returns are subject to review and adjustment by the relevant authorities, however very few cases are reviewed in actuality.

As regards income tax, it is calculated as follows: gross income minus exemptions, deductions and personal exemptions. Gross income includes "all income regardless of its origin" (in other words, any source of income). However, certain incomes are subject to tax exemptions at federal and/or state level. Such incomes are reduced by tax deductions, including in the case of most businesses, but there are expenditures not related to the business sector that benefit from deductions.

Table 1. Income tax rates in the USA

\begin{tabular}{|c|l|l|l|l|}
\hline $\begin{array}{c}\text { Marginal } \\
\text { tax rate }\end{array}$ & \multicolumn{1}{|c|}{$\begin{array}{c}\text { Unmarried } \\
\text { person }\end{array}$} & $\begin{array}{c}\text { Married person or } \\
\text { surviving spouse }\end{array}$ & $\begin{array}{c}\text { Married filing } \\
\text { separately }\end{array}$ & \multicolumn{1}{c|}{$\begin{array}{c}\text { Head of } \\
\text { household }\end{array}$} \\
\hline $\mathbf{1 0 \%}$ & $\$ 0-\$ 8,375$ & $\$ 0-\$ 16,750$ & $\$ 0-\$ 8,375$ & $\$ 0-\$ 11,950$ \\
\hline $\mathbf{1 5 \%}$ & $\$ 8,376-\$ 34,000$ & $\$ 16,751-\$ 68,000$ & $\$ 8,376-\$ 34,000$ & $\$ 11,951-\$ 45,550$ \\
\hline $\mathbf{2 5 \%}$ & $\$ 34,001-\$ 82,400$ & $\$ 68,001-\$ 137,300$ & $\$ 34,001-\$ 68,650$ & $\$ 45,551-\$ 117,650$ \\
\hline $\mathbf{2 8 \%}$ & $\$ 82,401-\$ 171,850$ & $\$ 137,301-\$ 209,250$ & $\$ 68,651-\$ 104,625$ & $\$ 117,651-\$ 190,550$ \\
\hline $\mathbf{3 3 \%}$ & $\$ 171,851-\$ 373,650$ & $\$ 209,251-\$ 373,650$ & $\$ 104,626-\$ 186,825$ & $\$ 190,551-\$ 373,650$ \\
\hline $\mathbf{3 5 \%}$ & $\$ 373,651+$ & $\$ 373,651+$ & $\$ 186,826+$ & $\$ 373,651+$ \\
\hline
\end{tabular}

Source: www.IRS.gov

The US tax system is extremely complicated, mainly because of progressive taxation and the deductions that it involves. Simplified to the maximum, personal income tax is progressive, depending on the size of gains. 
Dumiter F., Berlingher D., Opret A., Todor S. (2016)

Double taxation conventions, structure and evolution of the american tax system

There is, however, a broad system of deductions targeting, in particular, income from dividends and capital market, which is regressive, that is, it favors higher income. Thus, an employee who has an income of $\$ 40,000$ would be entitled to deductions exceeding $\$ 8,400$, while one who earns $\$ 200,000$ can easily benefit from deductions of up to $\$ 50,000$.

In general, income levels to which various tax rates apply vary depending on the category in which the taxpayer is registered. Thus, for married couples the income level from which tax rates begin to apply is generally higher, therefore total tax becomes lower. For families with high incomes, the amount paid as income tax is much higher than the amount paid in payroll taxes. Thus, any reduction in the income tax is more advantageous to high-income families than to low-income ones. (A reduction in payroll taxes would have the opposite effect).

\section{Corporate taxes}

The US tax system establishes, in the case of corporations, the payment of an income tax independent of shareholders. However, the latter are also required to pay taxes on dividends received from corporations where they hold shares. [1] There is, however, a notable difference in the case of partnerships, which are exempt from this tax. In this regard, some corporations wholly owned by US citizens or US residents may opt to be treated similarly to these partnerships; these rules are generally applicable to both federal and local taxes. As for charitable organizations, they have a different regime, in the sense that the tax due is applied only if the result is obtained from economic activities.

Table 2. Federal tax rates for corporate income

\begin{tabular}{|l|l|}
\hline \multicolumn{1}{|c|}{ Taxable income (\$) } & \multicolumn{1}{c|}{ Tax rate } \\
\hline 0 to 50,000 & $15 \%$ \\
\hline 50,000 to 75,000 & $\$ 7,500+25 \%$ of the amount exceeding 50,000 \\
\hline 75,000 to 100,000 & $\$ 13,750+34 \%$ of the amount exceeding 75,000 \\
\hline 100,000 to 335,000 & $\$ 22,250+39 \%$ of the amount exceeding 100,000 \\
\hline 335,000 to $10,000,000$ & $\$ 113,900+34 \%$ of the amount exceeding 335,000 \\
\hline $10,000,000$ to $15,000,000$ & $\$ 3,400,000+35 \%$ of the amount exceeding $10,000,000$ \\
\hline $15,000,000$ to $18,333,333$ & $\$ 5,150,000+38 \%$ of the amount exceeding $15,000,000$ \\
\hline Over $18,333,333$ & $35 \%-$ \\
\hline
\end{tabular}

Source: Instructions for Form 1120

The aforementioned federal taxes add to taxes imposed by states; the rates of such taxes differ from one state to another, depending on their degree of economic development. 
The US tax system, at both federal and state level, follows the principle of accountability, self-assessment by the taxpayer of how to generate income, and correct quarterly payment of taxes without prior evaluation by the authorities.

Deductions from taxable income are made by the employer, as are other wage deductions corresponding to social welfare and social insurance services. These taxes are paid by the employer to the relevant governmental institutions featured in the employee's account.

The tax measures imposed by the US government provide the certainty that taxes are paid first and on time, that the money will not be spent for other purposes, and that the government will use these funds to meet all obligations.

\section{The "network" of double taxation conventions developed by the US tax system}

International double taxation is the direct taxation of the same taxable matter and for the same period of time, by public authorities from different countries. [2]

Taking the role of sovereign imposing taxes, each state has found a way to regulate issues not only in the matter of taxing its own citizens, but also those individuals (non-residents) that earn occasional or temporary income on the territory of the state. [3]

Of course, such taxation is only applicable if the residents of a country earn income or own property in other countries. As, in the extreme case of certain taxes being levied once, but by two or more juxtaposed (not parallel) tax authorities from the same country, the double, triple or multiple taxation (exaggerated in practice) is an (oppressive) reality, but it is not considered in the theory of public finance as a double, triple or multiple legal taxation, but as an economic one, which actually translates into increased average tax burden borne by that taxpayer in their own country.

Amid enhanced domestic and international trade relations, natural and legal persons earn income or own property under different tax authorities, within the same state, or in different states. Therefore, it has become necessary to define the powers of the authorities of the same state or different states in matters of income tax, since these taxable objects are likely to be disputed simultaneously by several such entities.

Analyzing the literature in the field of financial and tax law, we can see that some renowned authors have studied the issue of international double taxation [4], [5], [6], [7], [8], highlighting strengths and weaknesses, progress made, and the challenges that we must face in the future. Other authors have conducted various studies and articles in which they undertook a comparative and critical analysis regarding the manifestation and application of double taxation agreements, through the four methods of avoiding double taxation [9], [10], [11], [12], [13]. 


\section{JOURNAL OF LEGAL STUDIES}

"Vasile Goldiș" Western University of Arad

Dumiter F., Berlingher D., Opret A., Todor S. (2016)

Double taxation conventions, structure and evolution of the american tax system

However, we have seen studies by authors from Romania who were concerned with identifying cases of international double taxation [14], [15], [16], [17], as well as other authors who analyzed the application of certain methods for avoiding double taxation, either within Romania or in comparison with other countries in Central and Eastern Europe [18], [19], [20].

Considering the international double taxation agreements concluded by the US, Annex 1 shows a brief overview of the current situation. According to Annex 1, there are 155 agreements with various countries around the world. Among them, the most common is the agreement on income and capital ratified by 60 countries, the first convention on income and capital having been signed on 20.02.1950 with Greece, while the most recent was signed with Chile on 04.02.2010. Another double taxation agreement concerns sea and air transport, concluded with a number of 35 countries, the oldest with Iceland, dating from 27/12/1962, and the most recent with Malta, dated 03.11.1997. Other agreements: cooperation and information exchange - Guyana (07/22/1992), Honduras (27.09.1990); Arbitration - Luxembourg (03.04.1996), the Netherlands (12/18/1992), Switzerland (23.01.2003), Spain (02/22/1909); protocol cooperation - Australia (27.09.2002), Canada (07/29/1997), Germany (14.12.1998), Mexico (26.11.2002), the UK (19.07.2002); tax implementation agreements - the oldest concluded with Samoa (01.01.1998), the most recent with Japan (06.11.2003); and the only one concluded on social security is the one with Japan, on 19.02.2004.

\section{Concluding remarks}

Given the analysis carried out on the US tax system, we can see that tax levies play an important role in the economy of this country. Thus, we can see a vast, wellstructured and grounded system, despite its complexity, organized on several levels, each with its own rules and collection agents, a system that can often "press" like a "vise" on taxpayers in the country with the strongest economy in the world.

Even with the strong recession that has affected the United States economy during the financial crisis, we can see that tax revenues account for almost a third of the country's GDP. Therefore, we are talking about one of the most important means available to public finances in their attempt to act on the economy, along with budget, money and credit. As a result, we can see that policies such as tax are used by the state to correct the current shortcomings of the market on income distribution, use of labor, adjusting price levels or increasing production, encouraging certain factors considered to be positive and deterring negative ones. The US tax system is not very flexible, an important part of levies coming from personal income tax and corporate income tax, respectively. Given the challenges that globalization will generate on the US economy (which may include the free movement of persons who earn income and obtain wealth simultaneously in 
several countries and locations, tax havens, practices such as treaty shopping), revenues and profits can register declining trends, and in this case the imposition of taxes that are too high can be even more harmful.

A possible solution to this situation could be a new tax reform. As mentioned above, the US tax system has gone through several such restructurings, for either economic or political reasons. These have been more or less successful, and now they are again at a crossroads. One cannot know whether such an approach will have the desired effects, but under conditions of increased spending and continued decrease in tax revenues, the economy could get into a real impasse of which it could hardly get out.

Regarding the network of double taxation conventions that the US is currently practicing, we see that this is particularly complex, the artisans of fiscal policy being continuously concerned with reducing the scale of "loopholes" through which incomes and capitals can be misappropriated or truncated. If we were to make a comparison with other countries that have concluded a double taxation convention, the number, size and history of the ones concluded with the US decisively surpass other countries, even from the developed world.

Following the analysis of over 150 double taxation conventions concluded by the US, it can be seen that such a developed country can be a model of good practice in international tax policy. Double taxation conventions are highly diverse, with a broad scope and manifestation: income, income and capital, inheritance and donations, sea and air transport, cooperation and information exchange, social security, protocol, arbitration, etc.

The US tax system is impressive in its organization and complexity, but this system is marred by the difficulties of changes needed in tax legislation, as well as a lack of transparency in terms of actual amounts paid as taxes to the state by individual and corporate taxpayers.

In conclusion, the US tax system, despite certain shortcomings and the difficult situation it faced during the financial crisis, is really impressive and able to sustain and remedy the United States economy under conditions of asymmetric shocks, both economic and legislative or political, if it is applied and managed properly.

\section{References}

[1] Alexandru, M., (2003), Dubla impunere internationala, Modalitati de evitare, Editura Economica, Bucuresti.

[2] *** - Manualul afacerilor europene, Institutul European din Romania (IER) University of Leuven - Belgia.

[3] Tatu, L., Serbanescu, C., Stefan, D., Catarama, D., Nica, A., Miricescu, E.C., (2013), Fiscalitate: de la lege la practica, Editura C.H. Beck, Bucuresti.

[4] Reimer, E., Rust A., (2015), Klaus Vogel on Double Taxation Conventions - Fourth Edition - Volume 1, Wolters Kluwer Law \& Business. 
Dumiter F., Berlingher D., Opret A., Todor S. (2016)

Double taxation conventions, structure and evolution of the american tax system

[5] Reimer, E., Rust A., (2015), Klaus Vogel on Double Taxation Conventions - Fourth Edition - Volume 2, Wolters Kluwer Law \& Business.

[6] Lang, M., (2013), Introduction to the Law of Double Taxation Conventions - Second edition, IBFD \& Linde, Amsterdam.

[7] Holmes, K., (2014), International Tax Policy and Double Taxation Tax Treaties - An Introduction to Principles and Application - Second Revised Edition, IBFD, Amsterdam.

[8] Rust, A., (2011), Double Taxation within the European Union - International Tax Conference of the University of Luxembourg, Wolters Kluwer Law \& Business.

[9] Ashta, A., (2007), Double taxation avoidance: International and Dididends, Burgundy School of Business - Social Science Research Network, pp. 1-14.

[10] Bufan, R., (2015), Fiscalitatea operatiunilor cu elemente de extraneitate I, Revista de Drept comercial, nr. 1/2005.

[11] Dickescheid, T., (2004), Exemption vs. Credit Method in International Double Taxation Treaties, International Tax and Public Finance, No.11, p. 721 - 739, 2004.

[12] Gerken, L., Markt, J., Schick, G. (2001), Double Income Taxation as Response to Tax Competition in the EU, Taxation - Intereconomics, September/October, p. $244-254$.

[13] Jourmard, I., (2002), Tax Systems in European Union Countries, OECD Economic Studies No. 34, I, p. 91-147.

[14] Grigorie-Lacrita, N., Morega, Dan, Iana, T., (2006), Eliminarea dublei impuneri juridice internationale in conditiile integrarii Romaniei in Uniunea Europeana, in Impozite si taxe v. 12, nr. 2, pp. 30-44.

[15] Grigorie-Lacrita, N., (2007), Evitarea dublei impuneri in conditiile integrarii Romaniei in Uniunea Europeana, in Impozite si taxe v. 13, nr. 11-12, pp. 86-89.

[16] Leter, C., Chirica S., (2010), Evitarea dublei impuneri fiscale internationale Reglementari legale interne si conventii fiscale incheiate de Romania, Economie teoretica si aplicata, Vol. XVII, No. 9(550), pp. $38-51$.

[17] Molico, T., (2007), Metode pentru evitarea dublei impuneri in practica conventionala internationala, in Contabilitatea, expertiza si auditul afacerilor nr. 9, pp. 54-57.

[18] Rus, I., Avram, E., Bocicor, P., Moldovan, M. Evitarea dublei impuneri intre Romania si statele: Ungaria si Bulgaria, Academica Science Journal - Studia Series, No. 3 - 2 2013, pp. $50-57,2013$.

[19] Herbei M., Dudas S., Costea A., (2010), Causes and Effects of the International Double Taxation. Solutions of the Conventions, Model for Avoiding the International Double Taxation, Finance - Challenges of the Future, Year IX, No. 12/2010, pp. 29 - 35. [20] Radu, M.E., (2012), International Double Taxation, Procedia - Social and Behavioral Sciences 62, pp. $403-407$. 
Dumiter F., Berlingher D., Opret A., Todor S. (2016)

Double taxation conventions, structure and evolution of the american tax system

\section{Annexes}

Total number of Agreements to avoid international double taxation

ANNEX 1 concluded by the USA

\begin{tabular}{|c|c|c|}
\hline Partner country & Type of agreement & $\begin{array}{c}\text { Date of } \\
\text { signature }\end{array}$ \\
\hline Argentina & Sea and air transport & 30.12 .1987 \\
\hline Argentina & Income and capital & 07.05 .1981 \\
\hline Aruba & Income and capital & 09.08 .1986 \\
\hline Australia & Income and capital & 16.08 .1982 \\
\hline Australia & Inheritance and donations & 14.05 .1953 \\
\hline Australia & Protocol & 27.09 .2002 \\
\hline Austria & Income and capital & 30.05 .1996 \\
\hline Austria & Inheritance and donations & 21.06 .1982 \\
\hline Austria & Arbitration & 31.05 .1996 \\
\hline Bahamas & Sea and air transport & 16.07 .1986 \\
\hline Bangladesh & Income & 26.09 .2004 \\
\hline Bangladesh & Income and capital & 06.10 .1980 \\
\hline Barbados & Cooperation and information exchange & 03.11 .1984 \\
\hline Barbados & Income and capital & 31.12 .1984 \\
\hline Belgium & Sea and air transport & 14.10 .1987 \\
\hline Belgium & Income and capital & 09.07 .1970 \\
\hline Bermuda & Cooperation and information exchange & 16.12 .1988 \\
\hline Bermuda & Individuals/Legal entities & 11.07 .1986 \\
\hline Bolivia & Sea and air transport & 23.11 .1987 \\
\hline Brazil & Sea and air transport & 01.01 .1997 \\
\hline Brazil & Cooperation and information exchange & 20.03 .2007 \\
\hline Bulgaria & Income & 23.02 .2007 \\
\hline Canada & Income and capital & 26.09 .1980 \\
\hline Canada & Protocol & 29.07 .1997 \\
\hline Chile & Sea and air transport & 31.12 .1975 \\
\hline Chile & Income and capital & 04.02 .2010 \\
\hline China & Sea and air transport & 05.03 .1982 \\
\hline China & Income and capital & 30.04 .1984 \\
\hline Columbia & Sea and air transport & 16.10 .1987 \\
\hline Costa Rica & Information exchange & 15.03 .1989 \\
\hline Cyprus & Sea and air transport & 13.11 .1989 \\
\hline Cyprus & Income and capital & 19.03 .1984 \\
\hline Czech Republic & Income and capital & 16.09 .1993 \\
\hline Czech Republic & Social security & 07.09 .2007 \\
\hline Denmark & Sea and air transport & 06.07 .1987 \\
\hline Denmark & Income and capital & 19.08 .1999 \\
\hline Denmark & Inheritance and donations & 27.04 .1983 \\
\hline
\end{tabular}


JOURNAL OF LEGAL STUDIES

"Vasile Goldiş" Western University of Arad

Dumiter F., Berlingher D., Opret A., Todor S. (2016)

Double taxation conventions, structure and evolution of the american tax system

\begin{tabular}{|c|c|c|}
\hline Denmark & Social security & 13.06 .2007 \\
\hline Dominica & Information exchange & 01.10 .1987 \\
\hline Egypt & Income and capital & 24.08 .1980 \\
\hline El Salvador & Sea and air transport & 17.12 .1987 \\
\hline Estonia & Income and capital & 15.01 .1998 \\
\hline Fiji & Sea and air transport & 19.06 .1996 \\
\hline Finland & Sea and air transport & 13.11 .1989 \\
\hline Finland & Income and capital & 21.09 .1989 \\
\hline Finland & Inheritance and donations & 03.03 .1952 \\
\hline Finland & Protocol & 31.05 .2006 \\
\hline Finland & Arbitration & 21.09 .1989 \\
\hline France & Income and capital & 31.08 .1994 \\
\hline France & Inheritance and donations & 24.11 .1978 \\
\hline Germany & Income and capital & 29.08 .1989 \\
\hline Germany & Inheritance and donations & 03.12 .1980 \\
\hline Germany & Protocol & 14.12 .1998 \\
\hline Germany & Arbitration & 29.08 .1989 \\
\hline Greece & Sea and air transport & 10.06 .1988 \\
\hline Greece & Income and capital & 20.02 .1950 \\
\hline Greece & Inheritance and donations & 20.02 .1950 \\
\hline Guam & Arbitration & 03.04 .1989 \\
\hline Guyana & Cooperation and information exchange & 22.07 .1992 \\
\hline Honduras & Cooperation and information exchange & 27.09 .1990 \\
\hline Hong Kong, China & Sea and air transport & 16.08 .1989 \\
\hline Hungary & Income and capital & 04.10 .2010 \\
\hline Iceland & Sea and air transport & 27.12 .1962 \\
\hline Iceland & Income & 23.10 .2007 \\
\hline Iceland & Income and capital & 07.05 .1975 \\
\hline India & Sea and air transport & 12.04 .1989 \\
\hline India & Income and capital & 12.09 .1989 \\
\hline India & Arbitration & 12.09 .1989 \\
\hline Indonesia & Income and capital & 11.07 .1988 \\
\hline Indonesia & Arbitration & 11.07 .1988 \\
\hline Ireland & Income and capital & 28.07 .1997 \\
\hline Ireland & Inheritance and donations & 13.09 .1949 \\
\hline Isle of Man & Sea and air transport & 01.08 .1989 \\
\hline Israel & Income and capital & 20.11 .1975 \\
\hline Italy & Income and capital & 25.08 .1999 \\
\hline Italy & Inheritance and donations & 30.03 .1955 \\
\hline Jamaica & Cooperation and information exchange & 18.12 .1986 \\
\hline Jamaica & Income and capital & 21.05 .1980 \\
\hline Japan & Tax implementation agreements & 06.11 .2003 \\
\hline Japan & Sea and air transport & 29.08 .1989 \\
\hline
\end{tabular}


JOURNAL OF LEGAL STUDIES

"Vasile Goldiș" Western University of Arad

Dumiter F., Berlingher D., Opret A., Todor S. (2016)

Double taxation conventions, structure and evolution of the american tax system

\begin{tabular}{|c|c|c|}
\hline Japan & Income and capital & 04.11 .2003 \\
\hline Japan & Inheritance and donations & 16.04 .1954 \\
\hline Japan & Social security & 19.02 .2004 \\
\hline Jordan & Sea and air transport & 20.06 .1974 \\
\hline Kazakhstan & Income and capital & 24.10 .1993 \\
\hline Kazakhstan & Arbitration & 24.10 .1993 \\
\hline Korea, Republic of & Income & 04.06 .1976 \\
\hline Latvia & Income and capital & 15.01 .1998 \\
\hline Liberia & Sea and air transport & 23.10 .1987 \\
\hline Lithuania & Income and capital & 15.01 .1998 \\
\hline Luxembourg & Sea and air transport & 11.04 .1989 \\
\hline Luxembourg & Income and capital & 03.04 .1996 \\
\hline Luxembourg & Arbitration & 03.04 .1996 \\
\hline Malaysia & Sea and air transport & 18.04 .1989 \\
\hline Malta & Sea and air transport & 11.03 .1997 \\
\hline Malta & Income & 08.08 .2008 \\
\hline Malta & Income and capital & 21.03 .1980 \\
\hline Marshall Islands & Sea and air transport & 05.12 .1989 \\
\hline Marshall Islands & Cooperation and information exchange & 14.03 .1991 \\
\hline Mexico & Sea and air transport & 07.08 .1989 \\
\hline Mexico & Cooperation and information exchange & 09.11 .1989 \\
\hline Mexico & Income and capital & 18.09 .1992 \\
\hline Mexico & Protocol & 26.11 .2002 \\
\hline Morocco & Income and capital & 01.08 .1977 \\
\hline Netherlands & Income and capital & 18.12 .1992 \\
\hline Netherlands & Inheritance and donations & 15.07 .1969 \\
\hline Netherlands & Arbitration & 18.12 .1992 \\
\hline Netherlands Antilles & Income and capital & 08.08 .1986 \\
\hline New Zealand & Income and capital & 23.07 .1982 \\
\hline Norway & Sea and air transport & 24.05 .1990 \\
\hline Norway & Income and capital & 03.12 .1971 \\
\hline Norway & Inheritance and donations & 13.06 .1949 \\
\hline Pakistan & Sea and air transport & 26.07 .1989 \\
\hline Pakistan & Income and capital & 01.07 .1957 \\
\hline Panama & Sea and air transport & 30.12 .1987 \\
\hline Peru & Sea and air transport & 23.05 .1989 \\
\hline Peru & Cooperation and information exchange & 15.02 .1990 \\
\hline Philippines & Income and capital & 01.10 .1976 \\
\hline Poland & Income and capital & 08.10 .1974 \\
\hline Portugal & Income and capital & 06.09 .1994 \\
\hline Puerto Rico & Cooperation and information exchange & 26.05 .1989 \\
\hline Romania & Income and capital & 04.12 .1973 \\
\hline Russian Federation & Sea and air transport & 18.07 .1994 \\
\hline
\end{tabular}

DE GRUYTER OPEN 


\section{JOURNAL OF LEGAL STUDIES}

"Vasile Goldiş" Western University of Arad

Dumiter F., Berlingher D., Opret A., Todor S. (2016)

Double taxation conventions, structure and evolution of the american tax system

\begin{tabular}{|c|c|c|}
\hline Russian Federation & Income and capital & 17.06 .1992 \\
\hline Saint Vincent and the Grenadines & Sea and air transport & 19.02 .1989 \\
\hline Samoa & Tax implementation agreements & 01.01 .1988 \\
\hline Singapore & Sea and air transport & 28.07 .1988 \\
\hline Slovakia & Income and capital & 03.10 .1993 \\
\hline Slovenia & Income and capital & 21.06 .1999 \\
\hline South Africa & Income and capital & 17.02 .1997 \\
\hline South Africa & Inheritance and donations & 10.04 .1947 \\
\hline Spain & Income and capital & 13.12 .1993 \\
\hline Spain & Arbitration & 22.02 .1990 \\
\hline Sri Lanka & Income and capital & 14.03 .1985 \\
\hline Sri Lanka & Protocol & 20.09 .2002 \\
\hline Sweden & Sea and air transport & 24.07 .1987 \\
\hline Sweden & Income and capital & 01.09 .1994 \\
\hline Sweden & Inheritance and donations & 13.06 .1983 \\
\hline Switzerland & Income and capital & 02.10 .1996 \\
\hline Switzerland & Inheritance and donations & 09.07 .1951 \\
\hline Switzerland & Arbitration & 23.01 .2003 \\
\hline Taiwan, Province of China & Sea and air transport & 13.11 .1989 \\
\hline Thailand & Income and capital & 26.11 .1996 \\
\hline Trinidad \& Tobago & Cooperation and information exchange & 11.01 .1989 \\
\hline Trinidad \& Tobago & Income and capital & 09.01 .1970 \\
\hline Tunisia & Income and capital & 17.06.1985 \\
\hline Tunisia & Arbitration & 10.10 .1989 \\
\hline Turkey & Income and capital & 28.03 .1997 \\
\hline Turkey & Arbitration & 28.03 .1996 \\
\hline Ukraine & Income and capital & 04.03 .1994 \\
\hline United Kingdom & Income and capital & 31.12 .1975 \\
\hline United Kingdom & Inheritance and donations & 19.10 .1978 \\
\hline United Kingdom & Protocol & 19.07.2002 \\
\hline Venezuela & Sea and air transport & 29.12 .1987 \\
\hline Venezuela & Income and capital & 25.01 .1999 \\
\hline
\end{tabular}

Source: Compiled by the authors based on data available in the database of the United Nations Conference on Trade and Development 